\title{
Crapemyrtle Bark Scale: A New Threat for Crapemyrtles, a Popular Landscape Plant in the U.S.
}

\author{
Zinan Wang ${ }^{1}$, Yan Chen ${ }^{2}$, Mengmeng Gu ${ }^{3}$, Erfan Vafaie ${ }^{4}$, Michael Merchant ${ }^{5}$ and \\ Rodrigo Diaz ${ }^{1, *}$ \\ 1 Department of Entomology, Agricultural Center, Louisiana State University, Baton Rouge, LA 70803, USA; \\ wangzinan2014@gmail.com \\ 2 Hammond Research Station, Agricultural Center, Louisiana State University, Hammond, LA 70403, USA; \\ YaChen@agcenter.lsu.edu \\ 3 Department of Horticultural Science, Texas A\&M AgriLife Extension Service, College Station, TX 77843, \\ USA; mgu@tamu.edu \\ 4 Department of Entomology, Texas A\&M AgriLife Research \& Extension Center, Overton, TX 75684, USA; \\ Erfan.Vafaie@ag.tamu.edu \\ 5 Department of Entomology, Texas A\&M AgriLife Research \& Extension Center, Dallas, TX 75252, USA; \\ m-merchant@tamu.edu \\ * Correspondence: RDiaz@agcenter.lsu.edu; Tel.: +1-225-578-1835
}

Academic Editor: Mary L. Cornelius

Received: 25 October 2016; Accepted: 9 December 2016; Published: 16 December 2016

\begin{abstract}
Crapemyrtle bark scale, Acanthococcus (=Eriococcus) lagerstroemiae (Kuwana) (Hemiptera: Eriococcidae), is a newly introduced insect pest on crapemyrtles, Lagerstroemia spp. (Myrtales: Lythraceae), one of the most popular flowering shrubs in the U.S. Since first detected in Texas in 2004, this pest has spread to twelve states causing losses to stakeholders. To develop a management plan, we reviewed current knowledge about the pest's biology and ecology, and suggested research approaches including studying its thermal tolerance, host range, plant resistance and biological control. Parasitoids and predators have been reared from A. lagerstroemiae in the U.S. and China. However, new surveys of natural enemies should be conducted in China, and studies on the host range and impacts of natural enemies on A. lagerstroemiae may help determine the potential for classical biological control. The life history, preying efficiency and rearing methods are important for coccinellid predators found in the U.S. including Chilocorus cacti L. and Hyperaspis spp. To enhance natural enemy performance, it is important to evaluate a sustainable insecticide program that considers efficacy, timing, rate and impact on pollinator health. Finally, an integrated management program of $A$. lagerstroemiae is discussed including planting resistant cultivars, using host specific natural enemies, and prudent use of insecticides.
\end{abstract}

Keywords: Acanthococcus lagerstroemiae (Kuwana); exotic species; integrated pest management; host resistance; biological control; parasitoids; Chilocorus cacti L.; Hyperaspis spp.

\section{Introduction}

Crapemyrtles, Lagerstroemia spp. L. (Myrtales: Lythraceae), are popular flowering shrubs and small trees around the world. Native to Southeast Asia and Australia, including China, Japan, India, Australia and Oceania [1], crapemyrtles have been introduced into the U.S. as ornamentals for 180 years [2]. Crapemyrtles have become a dominant landscape tree in the southern U.S. with an annual wholesale value of approximately $\$ 66$ million in 2014 [3]. Breeding programs over the last 35 years have produced superior varieties in a wide range of plant sizes and growing habits with improved flowering, new flower and foliage colors, ornamental bark, increased vigor and adaptability to a wide range of soil types $[2,4]$. In the U.S., crapemyrtle is hardy from USDA Plant Hardiness Zone 
6 to 10 (temperature ranging from $-23.3^{\circ} \mathrm{C}$ to $-1.1^{\circ} \mathrm{C}$ ), while its roots are believed to be winter hardy in Zone 5 (temperature ranging from $-28.9^{\circ} \mathrm{C}$ to $-23.3^{\circ} \mathrm{C}$ ) [2].

Crapemyrtles are valued for their relatively easy maintenance and limited pest problems [2,4]. The main diseases of crapemyrtle are powdery mildew caused by the fungus Erysiphe australiana (=lagerstroemiae) (McAlpine) U. Braun \& S. Takamatsu (Erysiphales: Erysiphaceae), and Cercospora leaf spot caused by Pseudocercospora lythracearum (Heald \& Wolf) Liu \& Guo (Capnodiales: Mycosphaerellaceae) [2]. Until the discovery of Acanthococcus lagerstroemiae (Kuwana) (Hemiptera: Eriococcidae), commonly referred to as the crapemyrtle bark scale, the primary insect pests of crapemyrtle were the crapemyrtle aphid, Sarucallis (=Tinocallis) kahawaluokalani (Kirkaldy) (Hemiptera: Aphididae) and the Japanese beetle, Popillia japonica Newman (Coleoptera: Scarabaeidae), followed by flea beetles, Altica spp. Geoffroy (Coleoptera: Chrysomelidae), and the granulate ambrosia beetle, Xylosandrus crassiusculus (Motschulsky) (Coleoptera: Curculionidae) [2]. However, these pests on crapemyrtles can largely be managed with resistant cultivars, landscape planning including plant placement in sunny locations with good ventilation; monitoring programs with optimal traps and rapid response including trunk sprays or the removal of infested plants; and environmentally friendly insecticides including insecticidal soaps or horticultural oils $[2,4,5]$.

The crapemyrtle bark scale, A. lagerstroemiae, is a newly introduced insect pest of crapemyrtles in the U.S. Native to Asia, A. lagerstroemiae was first reported in 2004 in a nursery in Richardson, TX, (Dallas County) [6]. The wide distribution of crapemyrtles in the U.S. may facilitate the rapid spread of A. lagerstroemiae. Associated with accumulation of black sooty mold (Figure 1), A. lagerstroemiae infestations could cause aesthetic damage to crapemyrtle [4,7]. Because of this plant damage, A. lagerstroemiae was recognized as one of the top nine pests in 2015 by the Greenhouse Grower magazine [8].

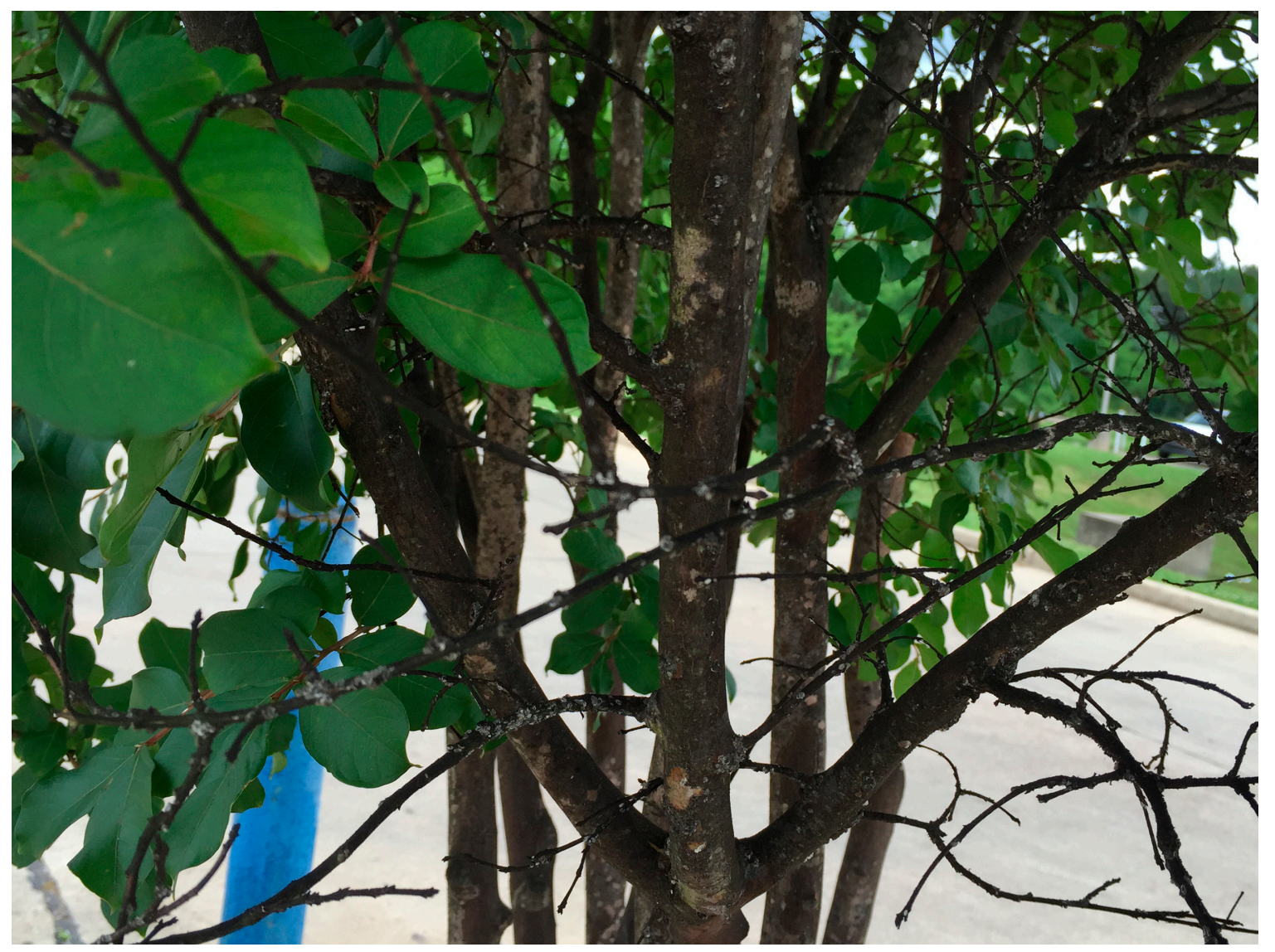

Figure 1. Branch dieback and accumulation of black sooty mold on the crapemyrtle tree infested with Acanthococcus lagerstroemiae. 
Information on the biology, ecology and control of A. lagerstroemiae is limited, and most comes from field observations in different regions in Asia. For example, the number of generations of A. lagerstroemiae ranged from two to four per year depending on the location [9-12]. Management strategies have focused on chemical control including the use of cypermethrin emulsion and lime sulfur, which reported to be effective in suppressing nymphs in China [9,13]. However, information on overwintering ecology, host plant resistance, and biological control remains unknown. The objectives of this review are to present current knowledge about the biology and ecology of A. lagerstroemiae, and to suggest research approaches for implementing integrated pest management (IPM) programs focusing on pest's thermal tolerance, host range, and the evaluation for host plant resistance and biological control.

\section{Taxonomy}

Acanthococcus lagerstroemiae (Kuwana), formerly Eriococcus lagerstroemiae Kuwana (Hemiptera: Eriococcidae), was combined into the genus Acanthococcus (Acanthococcidae) in 2013 along with 345 other species [14]. The family Eriococcidae sensu lato contained about 80 species in 10 genera in the U.S. [15], with some important ornamental plant scale pests. Kozar et al. (2013) placed most of these scales into Acanthococcidae (Group Family), for example, Acanthococcus (=Eriococcus) azalea (Comstock) on azaleas and Gossyparia spuria (Modeer) on elms [14,16]. The definition and borderlines of the family Eriococcidae (or Acanthococcidae) is still debated among coccidologists due to its diverse morphology and behavior [14,15]. Molecular analyses using the nuclear small subunit ribosomal RNA gene (SSU rRNA or 18S) also suggested the polyphyletic relationships within genus Eriococcus sensu lato [17]. Here we refer to the crapemyrtle bark scale as A. lagerstroemiae based on a latest review of the genus $[14,18]$.

\section{Biology}

Acanthococcus lagerstroemiae has the same incomplete metamorphosis as other species in the superfamily Coccoidea [19]. The female is paedomorphic, meaning that its form resembles that of a nymph $[4,7]$. The male turns into an alate without mouthparts after the prepupal and the pupal stage [7]. Eggs are $0.35 \pm 0.05 \mathrm{~mm}$ (mean \pm standard error) long, $0.15 \pm 0.05 \mathrm{~mm}$ wide $(\mathrm{n}=20)$, pink, and surrounded with white filaments (Figure 2a). Eggs are laid inside the white felt-like covering secreted by the female.

Nymphs are pink and mobile (Figure 2b). The first instars or crawlers are $0.5 \pm 0.1 \mathrm{~mm}$ long and $0.15 \pm 0.05 \mathrm{~mm}$ wide $(\mathrm{n}=20)$. After hatching, crawlers settle on the woody parts of the stem and new growth. Three nymphal stages were observed [7]. Nymphs and females secrete honeydew as a result of feeding.

Male pre-pupae and pupae are pink, non-feeding, immobile, and completely enclosed by white sacs (Figure 2c). Male pre-pupae are $0.9 \pm 0.1 \mathrm{~mm}$ long, $0.4 \pm 0.1 \mathrm{~mm}$ wide $(\mathrm{n}=20)$, and male pupae are $1.2 \pm 0.1 \mathrm{~mm}$ long and $0.5 \pm 0.1 \mathrm{~mm}$ wide $(\mathrm{n}=20)$ (Figure $2 \mathrm{c}-1)$. The blackish eyes and wing pads in the pupal stage are distinct from the pre-pupae (Figure 2c-2). Males are pink, alate, and have two long white filaments at the tip of the abdomen (Figure 2e). The mesothoracic wings have reduced venation, and the metathoracic wings have been lost along with the mouthparts. There are two pairs of ocelli each on dorsal and ventral side of the head, and a pair of smaller lateral ocelli. The filaments and extra ocelli have also been observed on other scales in Coccoidea which might function to stabilize the flight [20].

Females are $2.0 \pm 0.9 \mathrm{~mm}$ long, $1.2 \pm 0.6 \mathrm{~mm}$ wide $(\mathrm{n}=20)$, wingless, pink, and sessile (Figure $2 \mathrm{~d}$ ). Female shape and size varies according to the location of settling and presence of eggs inside the abdomen, but in general the size is much larger than the male. After production of the white ovisac, all eggs are laid, the female decreases in size and dies. The female white ovisac likely functions as a barrier against natural enemies and a mechanism to maintain humidity (Figure 2f). 


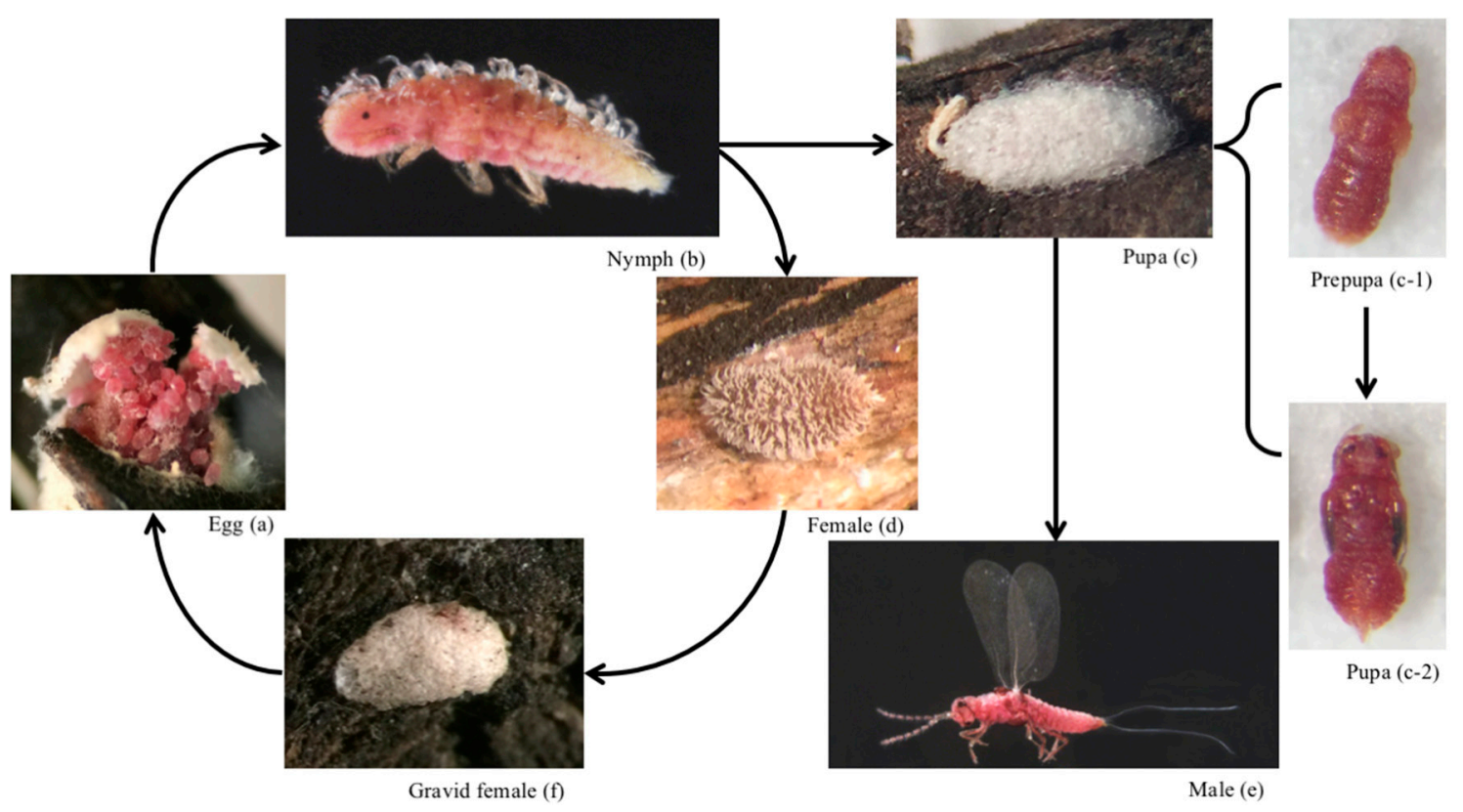

Figure 2. Life cycle of Acanthococcus lagerstroemiae: (a) Egg; (b) Nymph; (c) Pupa covered with white sac; (c-1) Prepupa; (c-2) Pupa; (d) Adult female; (e) Adult male; and (f) Ovisac containing the gravid adult female.

Acanthococcus lagerstroemiae has high fecundity and populations can grow rapidly. Females lay from 114 to 320 eggs during their lifetime [10]. After hatching and each molting, the crawlers and later instars disperse along the branches for one to two days and then become sessile [7]. Scales colonize the leaves, branches, twigs, trunk, stems and fruits. Some empirical evidence suggests that females and males have three and five nymphal stages, respectively [7]. Number of generations per year ranges from two to four depending on the climate in Asia [9-12] and is thought to be two to four in the U.S. [4]. In Anhui, China ( $\left.31^{\circ} 81^{\prime} \mathrm{N}, 117^{\circ} 21^{\prime} \mathrm{E}\right)$, two generations each year were observed [9], and the life cycle from egg to adult varied from 56 to 83 days [10]. In Guiyang, China $\left(26^{\circ} 41^{\prime} \mathrm{N}, 106^{\circ} 68^{\prime} \mathrm{E}\right)$ and Sichuan, China $\left(27^{\circ} 95^{\prime} \mathrm{N}, 102^{\circ} 21^{\prime} \mathrm{E}\right)$, four generations were recorded [11,12]. In Asia, A. lagerstroemiae overwinters as egg, nymph, prepupa and pupa $[9,11,21]$, while in the U.S., it has been reported to overwinter as nymphs [4].

\section{Host Range}

Host records revealed that $A$. lagerstroemiae not only attacks crapemyrtle but also other plant species in different families. In China, Japan, and Korea, this pest has been reported on thirteen other plants of ecological and economic importance (Table 1). For example, A. lagerstroemiae was reported to be a problem to pomegranate, Punica granatum L. (Myrtales: Lythraceae) in Pan Xi District, Sichuan, China $\left(27^{\circ} 02^{\prime} \mathrm{N}, 101^{\circ} 44^{\prime} \mathrm{E}\right)$, due to sooty mold accumulation [12]. Despite being present in the U.S. for more than ten years, A. lagerstroemiae has only been reported feeding on crapemyrtle [4] and American beautyberry (Callicarpa americana L.) [22]. Understanding the impact of A. lagerstroemiae to other plant species in the U.S. could help predict the potential economic damage and prevent its spread to other plant species. 
Table 1. Host plants of Acanthococcus lagerstroemiae in Asia and Hungary (except for Lagerstroemia spp.).

\begin{tabular}{|c|c|c|c|c|c|}
\hline Scientific Name & Common Name & Order & Family & Country & Reference \\
\hline Anogeissus latifolia (Roxb. ex DC.) Wall. ex Guill. \& Perr. & Axlewood & Myrtales & Combretaceae & Korea & [23] \\
\hline Anogeissus sp. & - & Myrtales & Combretaceae & China & [24] \\
\hline Buxus microphylla Sieb. et Zucc. & Korean Boxwood & Buxales & Buxaceae & Korea & [25] \\
\hline Celtis sinensis Pers. & Chinese hackberry & Rosales & Cannabaceae & Korea & [25] \\
\hline Dalbergia eremicola Polhill & Indian rosewood & Fabales & Fabaceae & Korea & {$[23]$} \\
\hline Diospyros kaki Thunb. & Japanese persimmon & Ericales & Ebenaceae & Korea & {$[25,26]$} \\
\hline Ficus carica L. & Edible fig & Rosales & Moraceae & Korea & [25] \\
\hline Glochidion puberum (L.) Hutch & Needlebush & Malpighiales & Euphorbiaceae & China & {$[27]$} \\
\hline Glycine max (L.) Merr. & Soybean & Fabales & Fabaceae & China & [27] \\
\hline Ligustrum obtusifolium Sieb. et. Zucc. & Border privet & Lamiales & Oleaceae & - & [14] \\
\hline Malus pumila Mill. & Paradise apple & Rosales & Rosaceae & China & [27] \\
\hline Mallotus japonicus Muell. Arg. & Food wrapper plant & Malpighiales & Euphorbiaceae & Korea & {$[25,28]$} \\
\hline Myrtus sp. & Myrtle & Myrtales & Myrtus & Hungary & [14] \\
\hline Punica granatum L. & Pomegranate & Myrtales & Lythraceae & China and Korea & {$[25,27,28]$} \\
\hline Pseudocydonia sinensis Schneid. & Chinese-quince & Rosales & Rosaceae & Korea & [26] \\
\hline Rubus sp. & Brambles & Rosales & Rosaceae & Hungary & {$[14]$} \\
\hline
\end{tabular}




\section{Distribution and Dispersal}

Acanthococcus lagerstroemiae is widely distributed in Asia. The most northern and southern locations reported in Asia are Beijing, China $\left(40^{\circ} 12^{\prime} \mathrm{N}, 116^{\circ} 21^{\prime} \mathrm{E}\right)$ [29] and Tamil Nadu, India $\left(10^{\circ} 77^{\prime} \mathrm{N}\right.$, $78^{\circ} 71^{\prime}$ E) [30], respectively. It was reported in England [23] in 1915 in a nursery but has not been reported since then [31]. Since its first detection in 2004 [4], A. lagerstroemiae has been reported in the U.S. states of Alabama, Arkansas, Georgia, Louisiana, Mississippi, New Mexico, North Carolina, Oklahoma, Tennessee, Texas, Virginia [32], and Washington [33], as of August, 2016. To predict the potential geographic distribution of the scale, we performed a niche modeling exercise using worldwide locations (MaxEnt version 3.3.2; http://www.cs.princeton.edu/ schapire/maxent/) [34]. Eighty-two confirmed locations were used in the model, including 57 locations in the U.S., 22 locations in China, and one location each in Japan, Korea, and India, respectively (Table S1). We used altitude and 19 bioclimatic (bioclim) variables related to temperature and precipitation from the WORLDCLIM database (http:/ / www.worldclim.org) to predict the climatic suitability in the U.S. and Asia. The prediction suggested that $A$. lagerstroemiae has established in different climates, and perhaps has reached the upper geographical limit in the U.S. (Figure 3).

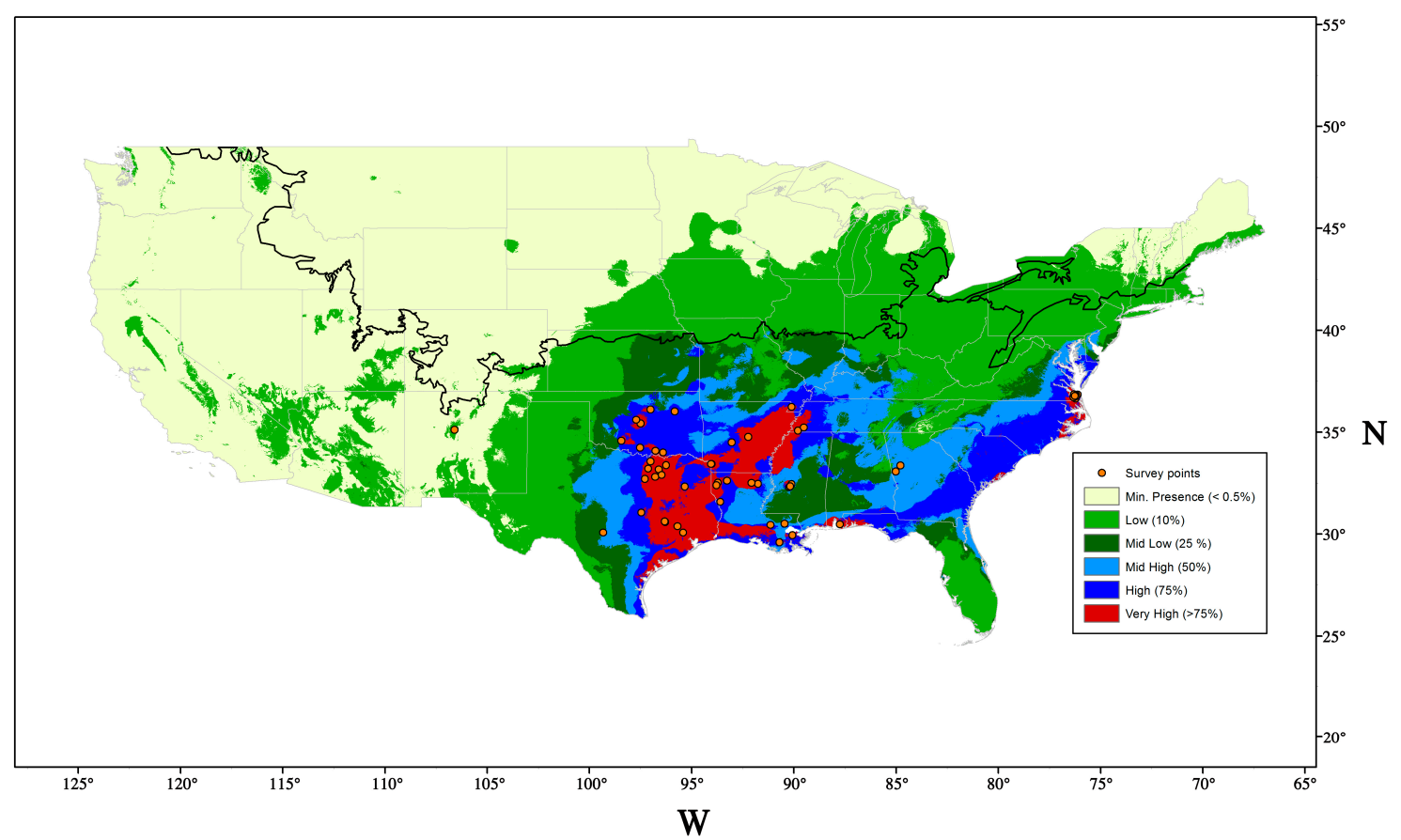

Figure 3. Projected distribution of Acanthococcus lagerstroemiae in the U.S. Warmer color indicates the higher climatic suitability. Orange points indicate the location of reported infestation. The black line indicates the upper limit of Plant Hardiness Zone 6.

Short distance dispersal of $A$. lagerstroemiae occurs by nymphs, and long-distance dispersal could be attributed to wind, birds, and human activities [4]. Morphological characters of crawlers could facilitate its dispersal by wind including flat and small body, relatively long legs, and lateral wax filaments on the body fringe [20]. Under experimental conditions, birds were capable of transferring nymphs of the hemlock woolly adelgid, Adelges tsugae (Annand) (Hemiptera: Adelgidae) by touching infested branches [35]. Crawlers of four armored scales, including Aspidiotus nerii Bouche (Hemiptera: Diaspididae), Abgrallaspis aguacatae Evans, Watson \& Miller, Hemiberlesia lataniae (Signoret), and Diaspidiotus perniciosus (Comstock), were found possessing a suction cup-like structure on hairs at the end of each leg, which can help them latch on larger insects to disperse [36]. We suspect $A$. lagerstroemiae could use larger animals to disperse. The discontinuous reports of A. lagerstroemiae in the U.S. (Figure 3. Survey points) suggested that human activities, trade and transportation of infested crapemyrtles 
could have facilitated the pest's long-distance movement. Measures should be taken to prevent further dispersal, for example, sales-stop restriction in reported area [37]. Potential distribution range estimated by climatic suitability and host range can help early detection and timely management.

\section{Plant Damage and Economic Impact}

Acanthococcus lagerstroemiae does cause significant damage to its host plant. Several instances suggested heavy infestation of $A$. lagerstroemiae could cause branch dieback (Figure 2) and stunt growth [10-12]. Limited empirical evidence has suggested a reduction in blossoms as a result of infestation with A. lagerstroemiae [38]. The scale secretes honeydew, which facilitates the growth of black sooty mold [4,10-12,39] and could interfere with plant photosynthesis; in addition, the coverage of ovisacs in the truck and branches is aesthetically displeasing. Extensive honeydew deposits and sooty mold can turn branches and trunks to an unappealing black color, significantly reducing landscape aesthetic value of infested plants [4]. However, relationship between population density of A. lagerstroemiae and different aspects of plant damage is still unclear. Research on this relationship may provide decision-making guidance on management options.

The economic impact of $A$. lagerstroemiae has not been quantified. However, failure to manage this exotic pest could lead to serious economic loss for wholesale and retail nurseries, landscape professionals, and consumers. To manage A. lagerstroemiae, nurseries would have to increase labor and insecticides which could result in greater costs [4]. This scale could also potentially decrease the production and market value of crapemyrtle because of reduced sales. In states such as Arkansas, Louisiana, Oklahoma, Tennessee, and Texas, the stop-sale restriction of crapemyrtle has been enacted in nurseries with A. lagerstroemiae infestation [37]. Because some of the potential hosts of A. lagerstroemiae are fruit crops of economic importance, for example, paradise apple, Japanese persimmon, pomegranate, fig, and brambles (Table 1), research to confirm host status of A. lagerstroemiae on these crops in the U.S. is critical for establishing preventive management measures.

\section{Natural Enemies}

Natural enemies of $A$. lagerstroemiae found in Asia and North America include predators and parasitoids. In Asia, the scale is attacked by the parasitoids Grandiclavula spatulata Zhang \& Huang [40], Metaphycus eriococci (Timberlake), Metaphycus cylindricus Wang, Li \& Zhang [41], Comperiella sp., Clausenia sp. [10], Metaphycus maculatus Agarwal [42] and Adelencyrtus longiclavatus Hayat, Alam and Agarwal [43] (Hymenoptera: Encyrtidae); and the predators Chilocorus kuwanae (Silvestri), Chilocorus rubidus Hope, Rodolia limbata Motschinsky, Propylaea japonica (Thunberg), Harmonia axyridis (Pallas) (Coleoptera: Coccinellidae), Chrysopa septempunctata Wesmael, and Chrysopa sinica (Tjeder) (Neuroptera: Chrysopidae) [10], and Cybocephalus nipponicus Endrody-Younga (Coleoptera: Coccinellidae) [44]. Chilocorus kuwanae was introduced to the U.S. from Korea in 1984 to help control euonymus scale, Unaspis euonymi (Comstock) (Hemiptera: Diaspididae), and was established in temperate regions (USDA Zone 7 or colder) of the U.S. after multiple releases [45].

In Louisiana, four ladybeetles (Coleoptera: Coccinellidae) were found associated with the infestation of $A$. lagerstroemiae, including two species of twice-stabbed lady beetle, Chilocorus cact $i \mathrm{~L}$. (Figure 4A,B) and Chilocorus stigma (Say), Hyperaspis bigeminata (Randall) (Figure 4C), and multicolored Asian ladybeetle, Harmonia axyridis (Pallas) [7]. In Texas, the ladybeetle, Hyperaspis lateralis Mulsant (Coleoptera: Coccinellidae) were observed in association with A. lagerstroemiae [46]. Field and laboratory observations in Louisiana further confirmed the predation of the cactus lady beetle, $C$. cact $i$ and H. bigeminata on A. lagerstroemiae [47] (Figure 4B,D). We collected field samples of A. lagerstroemiae nymphs in several locations in Beijing, China, during the summer and also in Louisiana during the fall of 2015. Three species of unidentified Hymenopteran parasitoids were reared from females in Beijing (Figure 5A-D), and one species from nymphs in Louisiana (Figure 5E). As these parasitoids have potential to be used in classical or augmentative biological control, their morphological and 
molecular identification need to be confirmed. In addition, a small predacious beetle C. nipponicus was reared from the colony of A. lagerstroemiae in Beijing, China in summer 2015 (Figure 5F).

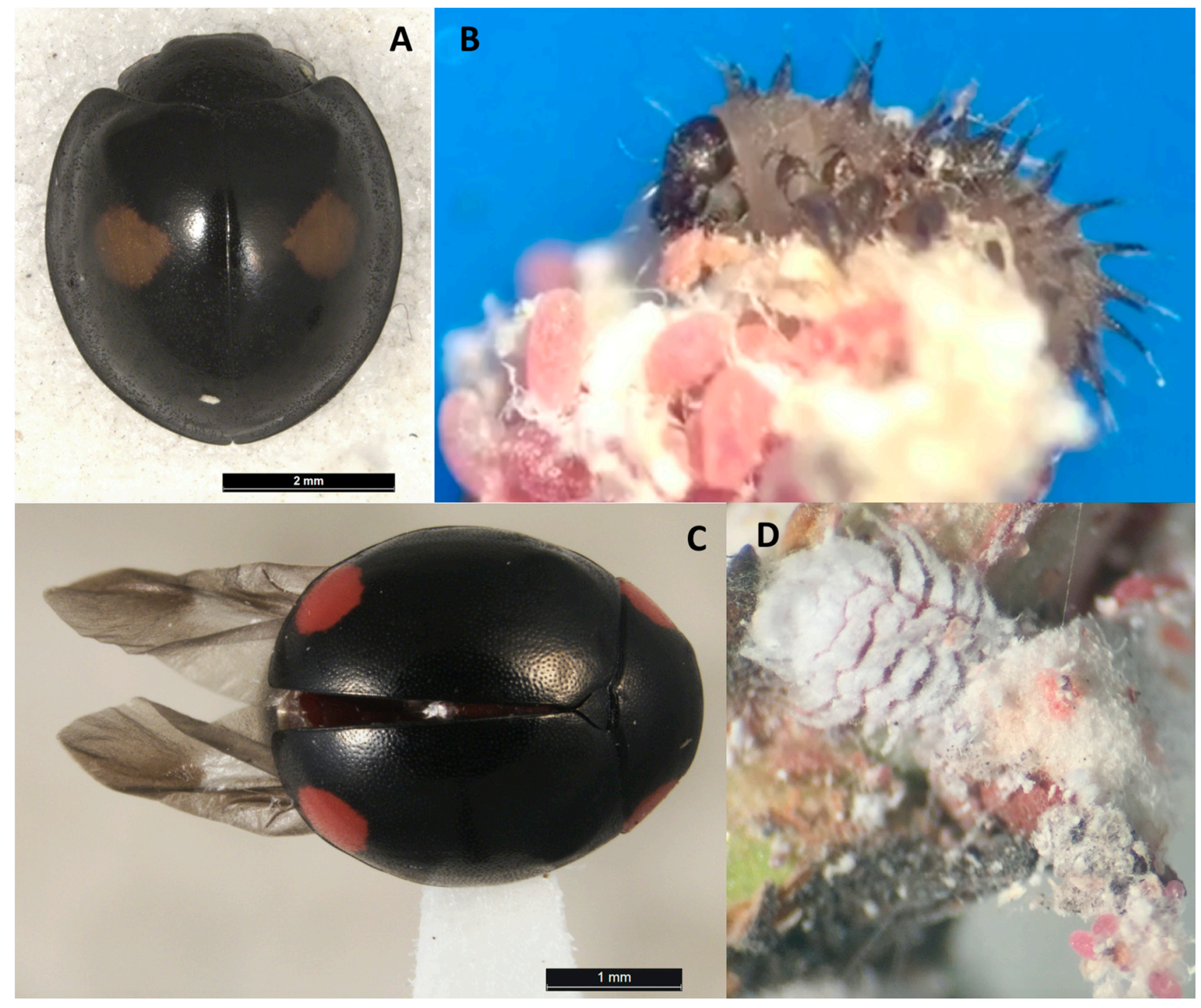

Figure 4. Predators of Acanthococcus lagerstroemiae found in Louisiana: (A) Adult of Chilocorus cacti; (B) Larva of Chilocorus cacti feeding on eggs of Acanthococcus lagerstroemiae; (C) Adult of Hyperaspis bigeminata; and (D) Larva of Hyperaspis bigeminata feeding on eggs of Acanthococcus lagerstroemiae. Voucher specimens of these two ladybeetles were deposited in Louisiana State Arthropod Museum at Louisiana State University.

Chilocorus cacti is a predator of eggs and crawlers of A. lagerstroemiae in Louisiana and Texas (Figure 4B) [47]. In the laboratory, fourth instar of C. cacti can feed on about 400 scale eggs over 24 h [47]. Chilocorus cacti has been used as a biological control agent for several scale pests. In 1966, this predator was introduced into South Africa from Texas to control the California red scale, Aonidiella aurantii (Maskell) (Hemiptera: Diaspididae) [48]. Despite high predation levels and widespread releases, C. cact $i$ established only in southwestern South Africa and failed to control A. aurantii, probably because of the extensive parasitism of C. cacti [49]. From 1987 to 1992, hundreds of C. cacti were released with other predators to control H. lataniae on kiwifruits, Actinidia deliciosa (A. Chev.) Liang et Ferguson (Ericales: Actinidiaceae) in New Zealand [50]. However, it failed to establish probably due to habitat destruction and pesticide use [51]. More research is needed to determine the potential of $C$. cacti as biological control agent for A. lagerstroemiae. 


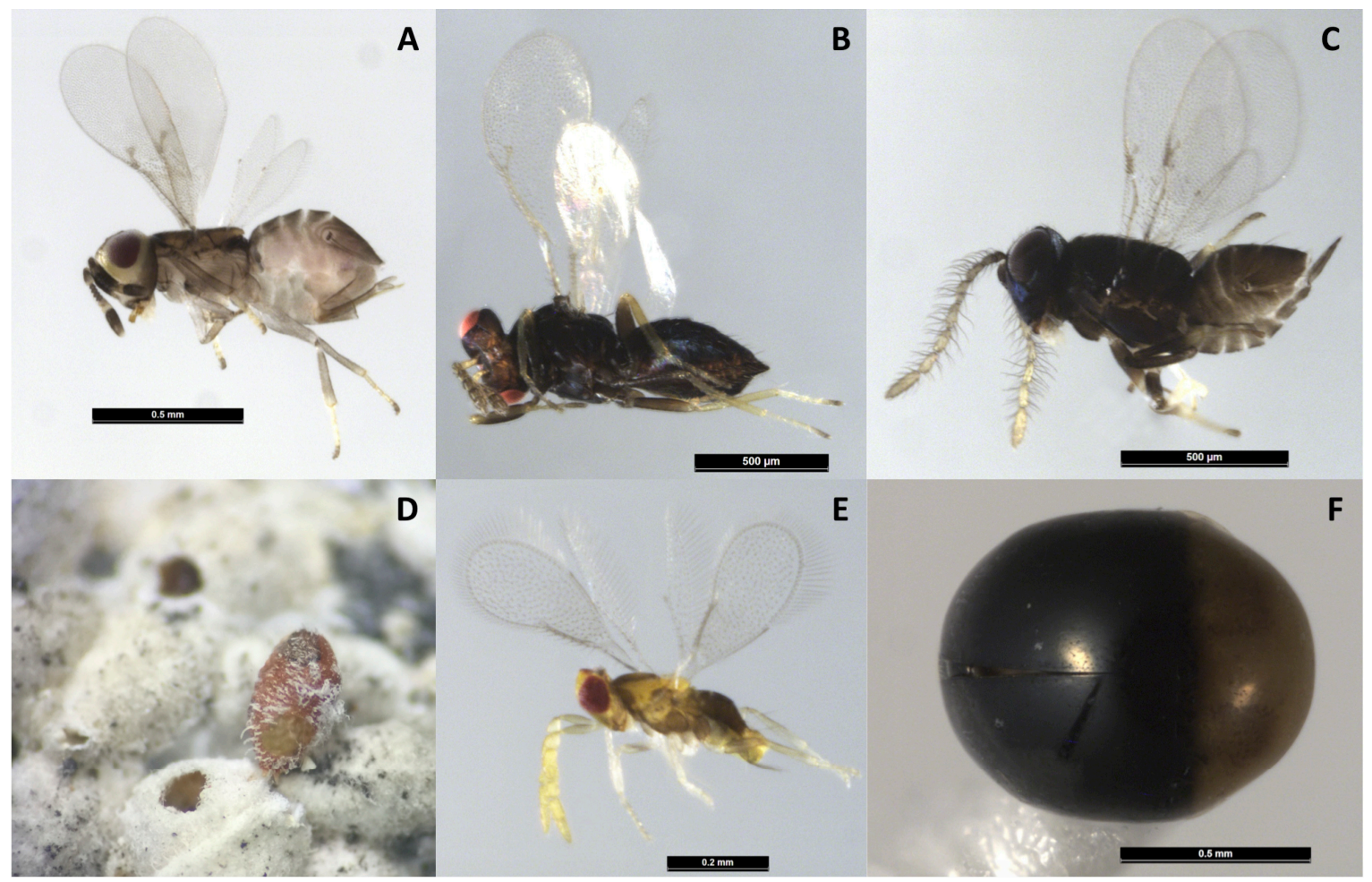

Figure 5. Parasitoids reared from Acanthococcus lagerstroemiae (A-C); caused damage in Beijing, China (D); the parasitoid reared in Louisiana, U.S. (E); and the predator, Cybocephalus nipponicus Endrody-Younga, reared from Acanthococcus lagerstroemiae in China (F). Voucher specimens of these natural enemies were deposited in Louisiana State Arthropod Museum at Louisiana State University.

\section{Current Management}

Acanthococcus lagerstroemiae is currently managed using chemical and/or mechanical methods in the U.S. The protective covering secreted by A. lagerstroemiae and its feeding behavior under bark crevices make control by contact insecticides difficult [4]. In China, lime sulfur, imidacloprid, cypermethrin, methidathion, dimethoate, abamectin, triazophos, and acetamiprid have been evaluated for controlling nymphs over one generation $[9,13,52,53]$. However, there is no information on the efficacy of these chemicals over more generations or subsequent years. Physical methods to reduce A. lagerstroemiae populations include brushing infested trunks with mild dishwashing solution, and removing scales and sooty mold with high water pressure washes $[4,6,39,54]$. Chemical control with soil-applied systemic neonicotinoids, such as dinotefuran and imidacloprid, are most effective [4]. Adding insect growth regulator or ultrafine oils as tank-mix or rotation partners may help with long-term control. Cost of chemical control is about $\$ 10$ per 10 -foot-tall tree using a rotation between two neonicotinoid insecticides as estimated by Bruce Nelms, ground manager of Louisiana State University Shreveport campus, who has been treating >100 infested crapemyrtles from 2013 to 2015 [55]. Negative impacts to pollinators and natural enemies may be a concern when applying these insecticides.

\section{Research Needed to Manage A. lagerstroemiae}

Currently, the only options to manage A. lagerstroemiae are using insecticides and/or mechanical methods. Resurgence of scale densities has been observed several times at the Hammond Research Station, Hammond, LA, after treatments of systemic insecticides at recommended rates [56]. Furthermore, insecticides including imidacloprid or cypermethrin have negative non-target effects on some invertebrates including pollinators and natural enemies [57]. An integrated strategy for 
managing A. lagerstroemiae should include preventative approaches and control methods with least ecological impact. The latter part of this review provides approaches to improve the integrated management of $A$. lagerstroemiae.

\subsection{Potential Distribution and Host Range}

There is a need to study A. lagerstroemiae thermal tolerance to understand the pest's phenology and its potential distribution in the U.S. Survival to temperature extremes is critical for the establishment and colonization of insects [58,59]. Mortality caused by cold and heat helps determine habitat suitability by a better understanding of the overwintering ability and heat-tolerance of exotic pests. For example, effects of cold temperatures to Microtheca ochroloma Stål (Coleoptera: Chrysomelidae) were studied by exposing different life stages of this chrysomelid to low temperatures for various time periods [60]. Upon the arrival of an exotic pest, thermal tolerance parameters can be useful for regulatory purposes to predict the potential distribution of the new pest in the adventive range. For example, cold tolerance of the invasive light brown apple moth, Epiphyas postvittana (Walker) (Lepidoptera: Tortricidae), first discovered in California in 2006, has been used to predict its potential geographic range [61]. Effects of low temperatures on mortality and oviposition of the root weevil, Diaprepes abbreviatus (L.) (Coleoptera: Curculionidae) were assessed to predict its future spread and area for searching potential natural enemies [62]. Similarly, knowledge of the thermal tolerance of A. lagerstroemiae could help predict its potential distribution in the U.S., thus providing geographic background for further research on its management.

Understanding plant species at risk of $A$. lagerstroemiae and estimating risks on host plants are critical for determining the pest's potential spread and economic impact. Multiple plant species in different families have been reported as hosts of $A$. lagerstroemiae in its native range, but most hosts present in the literature were solely derived from unconfirmed observations. Some reported hosts are ecologically and/or economically important to the U.S., for example, pomegranate production comprises more than 30,000 acres with a \$115 million value in Kern County, California alone [63]. Considering the potential and known economic values of horticultural and agronomic crops reported as alternative hosts in Asia, it is critical to evaluate all potential host plants at risk in the U.S. By using a centrifugal phylogenetic method [64], we can assess the ability of A. lagerstroemiae to develop (from crawlers to adult) and reproduce on plant species $[65,66]$ closely related to crapemyrtle or those that have been reported as alternative host plants [67]. Since adult females are sessile on the host plant, no-choice experiments and life-table analysis can help compare the scale's development, survival, reproduction and preference on selected plant species, as it has been conducted with other scales (Ex. Tectococcus ovatus Hempel (Hemiptera: Eriococcidae) [68]). With the host range information and preventative approaches, we can reduce or avoid economic losses to non-crapemyrtle hosts of A. lagerstroemiae in the U.S.

\subsection{Plant Resistance}

Host plant resistance is critical for developing IPM programs. Currently there is no published literature on crapemyrtle cultivar resistance to $A$. lagerstroemiae. With over 200 registered crapemyrtle cultivars and more than 100 cultivars commercially available in the U.S. [2], research should be conducted to study antibiosis and antixenosis of these cultivars to A. lagerstroemiae, which are adverse effects on the pest's biology and behavior, respectively [69]. Tolerance can be measured for crapemyrtle cultivars by documenting a significant decrease in flowering or growth compared to others.

Integration of plant resistance into an IPM program involves screening, breeding and implementation of cultivars [69]. Resistant genotypes of crapemyrtle to survival, growth and reproduction of A. lagerstroemiae can be screened under no-choice condition. Crapemyrtle cultivars demonstrating resistance to A. lagerstroemiae can be utilized as parents in breeding. For example, daily fecundity of crapemyrtle aphids on seven crapemyrtle cultivars were screened under no-choice condition, and L. indica was found to have higher resistance than L. fauriei and L. indica X fauriei hybrids [70]. After screening 
12 crapemyrtle cultivars, L. indica X fauriei hybrids with less mineral nutrient content in the leaves were less preferred by the flea beetle, Altica litigate Fall (Coleoptera: Chrysomelidae) [71]. At the Crapemyrtle Trails of McKinney and surrounding parks in McKinney, TX, there are more than 100 cultivars of crapemyrtles [72], providing sources for screening resistant cultivars. Scientists at the University of Florida and Texas A\&M AgriLife Research and Extension Center began screening of these crapemyrtle cultivars in 2014. Current molecular technologies can help understand mechanisms underlying resistant varieties and apply this resistance to help develop new cultivars. Genomic sequencing and transcriptomic analysis can identify genes with specific resistant traits, and the virus-induced gene silencing technologies can ultimately assign resistant functions of these genes to plants [73]. Crapemyrtle cultivars with resistance to A. lagerstroemiae can be utilized in landscapes and evaluated for efficacy and other control strategies.

\subsection{Biological Control}

Biological control could have higher benefit/cost ratio compared with chemical and/or mechanical control strategies in terms of reduced continuous expenditure of pesticides and labor, low impacts to beneficial insects, and low risks of pest resistance [74-76]. Chemical or mechanical methods to control $A$. lagerstroemiae could become cost prohibitive or labor-intensive for homeowners and nursery growers. A survey of socio-economic impact of the biological control of the mango mealybug, Rastrococcus invadens Williams (Hemiptera: Pseudococcidae), in Benin showed that after failed trials using both mechanical and chemical controls, the release of two parasitoids have successfully controlled the mealybug with a benefit/cost ratio of 145:1 [77]. Moreover, there is a long history of successful implementation of biological control programs against scale insects. For example, three parasitoids including Acerophagus papayae Noyes and Schauff, Pseudleptomastix mexicana Noyes and Schauff, and Anagyrus loecki Noyes and Menezes (Hymenoptera: Encyrtidae) were introduced to India in 2010 and successfully controlled the papaya mealybug Paracoccus marginatus Williams and Granara (Hemiptera: Pseudococcidae), which led to an estimated net benefit between \$524 million to $\$ 1.34$ billion over five years [78]. In 1995, several natural enemies, including Anagyrus kamali Moursi (Hymenoptera: Encyrtidae) and Cryptolaemus montrouzieri Mulsant (Coleoptera: Coccinellidae) were introduced and have since successfully reduced the population density of the pink hibiscus mealybug, Maconellicoccus hirsutus (Green) (Hemiptera: Pseudococcidae) in many areas of the Caribbean [79]. The estimated net benefit of the introduction in only Trinidad was $\$ 41$ million representing a socio-economic benefit/cost ratio of 8:1 for the period 1996-2024 [79]. Therefore, researchers should investigate the possibility of a biological control program for management of A. lagerstroemiae in the U.S. using classical, augmentative, and conservation biological control.

\subsubsection{Classical Biological Control}

The goal of classical biological control is to introduce natural enemies from the native area to reduce pest's populations in the adventive range. A classical biological control program involves the exploration, identification, importation, host range testing in quarantine, release and evaluation of natural enemies against $A$. lagerstroemiae in the introduced range [75].

Regions between Beijing and Jiangsu in China are ideal for exploration of natural enemies of A. lagerstroemiae. Based on previous climatic modeling of MaxEnt and USDA Plant Hardiness Zone Map, the northern distribution of the scale could be limited by winter temperatures and the distribution of crapemyrtle [80]. Regions with similar plant hardiness zones such as Jiangsu in China (Figure 6), Texas, and Louisiana in the U.S. (Figure 3), have very high climatic suitability (>75\%) for the survival of A. lagerstroemiae (Figure 6). Natural enemies adapted to colder winters can be explored in the region of Beijing. In 2015, a collaboration was established with Beijing Forestry University that would facilitate long-term explorations for natural enemies in China.

Highly specialized parasitoids and predators should be prioritized in a classical biological control program of $A$. lagerstroemiae considering its effectiveness in scale control. Parasitoids with a narrower 
host range pose less risk to the ecosystem than other natural enemies [81]. For example, the parasitoid Anagyrus sp. nov. nr. sinope Noyes \& Menezes demonstrated traits as potential biological control agents; and its highly specific to the cassava mealybug, Phenacoccus madeirensis Green (Hemiptera: Pseudococcidae), a pest attacking cassava, pineapple, citrus and potatoes [82]. Specialized predators are also good candidates for classical biological control programs. The vedalia beetle, Rodolia cardinalis (Mulsant) (Coleoptera: Coccinellidae) reduced the densities of the cottony cushion scale, Icerya purchasi Maskell (Hemiptera: Monophlebidae) [83], though this beetle's host range was determined to be exclusively cottony cushion scales only after their introduction [84]. For natural enemies already reared from Asia, more research on their biology, ecology and host range are needed. Before introduction, the host range of potential biological control agents should be studied in a quarantine facility and tests should include native and exotic scales in the U.S. [15,16], for example, A. azalea, E. quercus, G. spuria, and Eriococcus coccineus (Cockerell) (Hemiptera: Eriococcidae).

The functional response of parasitoids to A. lagerstroemiae measured in quarantine can generate practical information for future field releases and mass rearing. Post-release assessment with before-and-after experimental design can evaluate the impacts of parasitoids to A. lagerstroemiae in the field. Comparison before and after releasing three introduced encyrtids including A. papayae, P. mexicana, and A. loecki in classical biological control of P. marginatus in Tamil Nadu in 2010 showed a $9.7 \%$ reduction in the mealybug population one month after their release and $96.6 \%$ reduction after six months [85]. These assessments can also help estimate economic benefits and the costs of classical biological control programs.

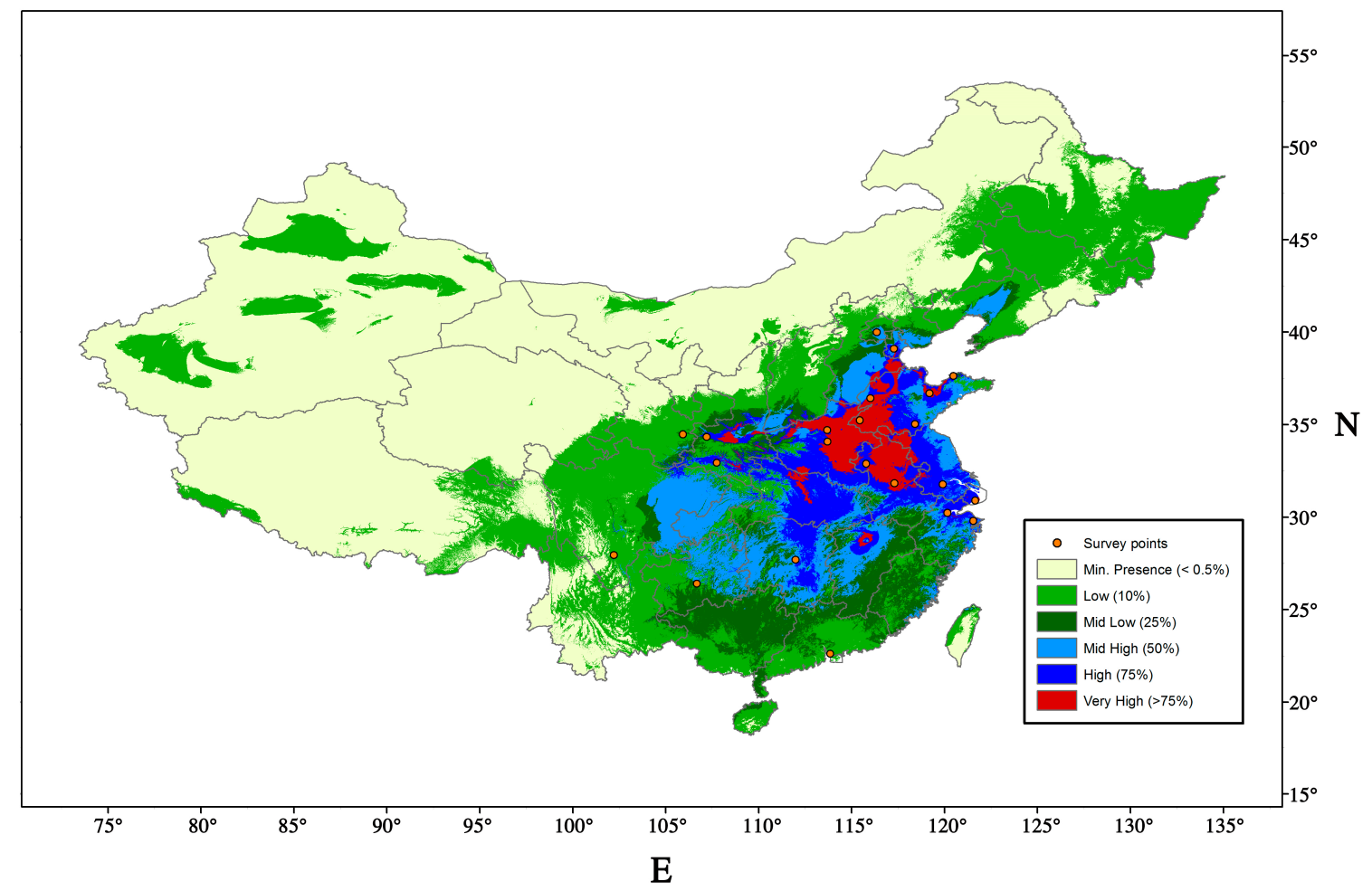

Figure 6. Projected distribution of Acanthococcus lagerstroemiae in China using MaxEnt. Warmer color indicates the higher climatic suitability. Orange points indicate the location of reported infestation.

\subsubsection{Augmentative Biological Control}

The goal of augmentative biological control is to increase the numbers of local natural enemies of A. lagerstroemiae. Chilocorus cacti and Hyperaspis spp. are predators of A. lagerstroemiae present in the southern U.S. $[7,46]$ and have potential for augmentative biological control. However, these two ladybeetles do not appear sufficient to suppress A. lagerstroemiae in the field, especially in October and 
November when temperature begins to decrease [86]. Augmentation of these two species could reduce the overall population of $A$. lagerstroemiae over a season. For example, 30 larvae of $C$. montrouzieri per plant were released in a pomelo orchard in August 2005, and $98 \%, 90 \%$ and $82 \%$ of populations of the citrus mealybug, Planococcus citri (Risso) (Hemiptera: Pseudococcidae), the striped mealybug, Ferrisia virgata (Cockerell) (Hemiptera: Pseudococcidae), and the spherical mealybug, Nipaecoccus viridis (Newstead) (Hemiptera: Pseudococcidae) were reduced, respectively [87].

To determine the potential of these two lady beetles in augmentative biological control, researchers need to understand their life history and voracity. Study of developmental time at different temperatures will enable researchers to construct population growth models. For example, temperature-dependent development of Chilocorus bipustulatus L. (Coleoptera: Coccinellidae) studied under seven different temperatures suggested its optimal temperature for development between 33.6 and $34.7^{\circ} \mathrm{C}$ and a thermal constant for total development of 474.7 degree-days [88]. Laboratory trials showed that eggs of $A$. lagerstroemiae can support $C$. cacti and H. bigeminata to develop from eggs to adults [47] and population growth models can help predict quantity and timing of release for optimal control. Similar to understand impacts of parasitoids, predation by these two ladybeetles can be assessed in the laboratory and field. Life history parameters and predation can be modeled to determine the impact of natural enemies to pest population dynamics. For example, the field life-table study of Coccus viridis (Green) (Hemiptera: Coccidae) in coffee plantations suggested nymphs to be the critical stage for mortality, and several coccinellid predators were considered an important factor contributing to scale mortality in the field [89]. Researchers need to conduct similar studies to determine the key life stages and factors causing mortality to A. lagerstroemiae in the field and determine timing for release of predators.

Rearing natural enemies can be challenging, but will be critical for conducting field augmentation studies. Chilocorus cacti has been studied as a biological control agent for scales that can be reared on live prey including A. nerii [49]. Dried wasp brood was tried as artificial diet for $C$. cacti but failed to support its oviposition [90]. No information about mass rearing of $H$. bigeminata has been reported in the literature. Culturing C. cacti and Hyperaspis spp. on A. lagerstroemiae may lead to problems including the discontinuity of food supply and the extra cost of rearing facilities and labor [91]. Future work could explore factitious prey or artificial diets based on vertebrate protein as alternatives for a mass rearing system, demonstrated successfully for other predators. For example, H. axyridis can be mass reared using eggs of the Angoumois grain moth, Sitotroga cerealella (Olivier) (Lepidoptera: Gelechiidae) as factitious prey [91], or the mixture of chicken egg yolk, chicken liver, sugar, casein enzymatic hydrolysate, soy oil, and different salts as artificial diet [92].

\subsubsection{Conservation Biological Control}

The goal of conservation is to enhance the performance or increase the population density of natural enemies present in the environment by improving the habitat or reducing the exposure to toxic insecticides [93]. Chemical control has an important role in suppressing pest density. When applying insecticides it is difficult to avoid residual effects on non-target organisms [94], however, measures can be taken to minimize detrimental effects. Currently, little is known about the non-target impact of recommended insecticides used against A. lagerstroemiae on C. cacti, Hyperaspis spp., and parasitoids reared from China; and research about the rates, timing and delivery (i.e., drench vs. bark spray) of insecticide applications is needed.

Natural enemy populations can have more difficulty rebounding after a broad-spectrum pesticide application compared to pests, such as organophosphate and carbamate insecticides [95], and to chemical residues [96]. Soil-applied systemic neonicotinoid insecticides, which are currently the recommended strategy for A. lagerstroemiae management [7], are less likely to directly contact non-target organisms, but may impact natural enemies through food sources such as pollen and/or nectar of surrounding plants $[95,97]$. A single foliar spray of imidacloprid was demonstrated to affect survival, egg production and egg hatching of C. septempunctata in a laboratory study [98]. 
In addition, neonicotinoid residues translocated into crapemyrtle pollen could further damage the natural enemy population by causing mortality and altering behavior, such as soil-applied imidacloprid on a mealybug parasitoid, Anagyrus pseudococci (Girault) [99], the pink spotted lady beetle, Coleomegilla maculata (DeGeer) (Coleoptera: Coccinellidae) [100] and the green lacewing, Chrysoperla carnea (Stephens) (Neuroptera: Chrysopidae) [101]. Decrease of natural enemies may result in resurgence of A. lagerstroemiae after applying neonicotinoid insecticides.

Using lower insecticide dosages or timing insecticides to avoid application when natural enemies are most abundant or most susceptible can help reduce negative impact on biological control agents and reduce development of pesticide resistance $[95,96,102]$. The application of dormant oil when nymphs lack wax coverage should be evaluated. Studies on the interactions between insecticides and natural enemies on A. lagerstroemiae populations are needed. For example, low dosage of the selective aphicide pymetrozine combined with two biological control agents, the seven-spotted lady beetle, Coccinella septempunctata L. (Coleoptera: Coccinellidae) and Diaeretiella rapae M'Intosh (Hymenoptera: Aphidiidae), reduced the cabbage aphid, Brevicoryne brassicae L. (Hemiptera: Aphididae) population by $98 \%$ in the laboratory [103]. Negative impacts of insecticides on natural enemies can be minimized by better timing applications when populations of natural enemies are absent, and/or in life stages most resistant to the insecticides $[96,102,104]$. Application in winter and early spring might reduce A. lagerstroemiae nymphs lacking coverings without substantially impacting beneficial insects and foliar sprays can help to deliver the products considering the low sap pressure of plants during winter. To maximize survival, natural enemies should be released when insecticide residues have declined [95].

\section{Conclusions}

A successful integrated pest management strategy of A. lagerstroemiae requires knowledge of the scale's biology and ecology, host range and damage to the host plant. Use of crapemyrtle varieties with high resistance to A. lagerstroemiae in the landscape can help improve pest management. Natural enemies may play an important role in the management of $A$. lagerstroemiae in the field and knowledge of the biology and ecology of natural enemies is needed. Classical biological control shows promise and can be started by searching for parasitoids of A. lagerstroemiae in regions between Beijing and Jiangsu in China. The potential for an augmentative biological control program should also be studied by investigating the efficiency of local arthropod predators in the U.S., including C. cacti and H. bigeminata, to manage $A$. lagerstroemiae populations. In addition, conservation biological control programs that include the use of narrow-range insecticides with minimal risks, reduced application rates and better timing of applications can improve IPM programs against $A$. lagerstroemiae.

Supplementary Materials: The following are available online at http://www.mdpi.com/2075-4450/7/4/78/s1, Table S1: Occurrence of infestation of Acanthococcus lagerstroemiae in the U.S. and Asia.

Acknowledgments: Juan Shi, Hanjun Yu, and Hao Wang from Beijing Forestry University, China, helped confirm the infestation of crapemyrtle bark scale in China and reared natural enemies from Beijing. Nan Shang provided excellent technical assistance in visualizing the potential distribution. We thank Christopher Carlton and Victoria Bayless from Louisiana State University for confirming identification of collected natural enemies. Gene Reagan from Louisiana State University provided helpful suggestions to the manuscript. The manuscript was improved by comments of four anonymous reviewers. This work was funded in part by the National Institute of Food and Agriculture, U.S. Department of Agriculture, under award number 2014-70006-22632.

Author Contributions: Zinan Wang and Rodrigo Diaz wrote the outline for the review paper. Zinan Wang, Yan Chen, Mengmeng Gu, Erfan Vafaie, Michael Merchant, and Rodrigo Diaz all contributed to the review paper.

Conflicts of Interest: The authors declare no conflict of interest.

\section{References}

1. Egolf, D.R.; Andrick, A.O. The Lagerstroemia Handbook/Checklist: A Guide to Crapemyrtle Cultivars; American Association of Botanical Gardens and Arboreta: Las Cruces, NM, USA, 1978; p. 9.

2. Chappell, M.R.; Kristine, B.S.; Williams-Woodward, J.; Knox, G. Optimizing plant health and pest management of Lagerstroemia spp. HortScience 2012, 30, 161-172. 
3. 2014 Census of Horticultural Specialities. Available online: https://www.agcensus.usda.gov/Publications / 2012/Online_Resources/Census_of_Horticulture_Specialties/(accessed on 16 May 2016).

4. Gu, M.; Merchant, M.; Robbins, J.; Hopkins, J. Crape Myrtle Bark Scale: A New Exotic Pest. Available online: https://www.eddmaps.org/cmbs/Resources/TAMUCrapemrytlebarkscaleEHT-049.pdf (accessed on 16 May 2016).

5. Knox, G. Crapemyrtle in Florida. Available online: http:/ /edis.ifas.ufl.edu/mg266 (accessed on 16 May 2016).

6. Merchant, M.E.; Gu, M.; Robbins, J.; Vafaie, E.; Barr, N.; Tripodi, A.D.; Szalanski, A.L. Discovery and Spread of Eriococcus lagerstroemiae Kuwana (Hemiptera: Eriococcidae), a New Invasive Pest of Crape Myrtle, Lagerstroemia spp. Available online: http://bugwoodcloud.org/resource/pdf/ESAPosterDiscovAndSpread2014. pdf (accessed on 16 May 2016).

7. Wang, Z.; Chen, Y.; Knox, G.W.; Diaz, R. Crape Myrtle Bark Scale. Available online: http://www.lsuagcenter.com/ $\sim /$ media/system/7/8/d/1/78d165df43ac0d4767607d88dadfb841/pub3440bugbizcrapemyrtlebarkscale_final. pdf (accessed on 16 May 2016).

8. Miller, C. Top 9 Pest Reports in the Past Two Years. Available online: http://www.greenhousegrower.com/ retailing/top-9-pest-reports-in-the-past-two-years/5/ (accessed on 17 May 2016).

9. He, D.; Cheng, J.; Zhao, H.; Chen, S. Biological characteristic and control efficacy of Eriococcus lagerstroemiae. Chin. Bull. Entomol. 2008, 5, 34. (In Chinese)

10. Jiang, N.; Xu, H. Observation on Eriococcus lagerstroemiae Kuwana. J. Anhui Agric. Univ. 1998, 25, $142-144$. (In Chinese)

11. Luo, Q.; Xie, X.; Zhou, L.; Wang, S.; Xu, Z. A study on the dynamics and biological characteristics of Eriococcus lagerstroemiae Kuwana population in Guiyang. Acta Entomol. Sin. 2000, 43, 35-41. (In Chinese)

12. Ma, J. Occurrence and biological characteristics of Eriococcus lagerostroemiae Kuwana in Panxi district. South China Fruits 2011, 5, 3. (In Chinese)

13. Zhang, Y. Effects of different insecticides on Eriococcus lagerstroemiae Kuwana (Hemiptera: Eriococcidae) in Changzhou district, Jiangsu. Hunan Agric. Sci. 2011, 14, 32-33. (In Chinese)

14. Kozar, F.; Kaydan, M.B.; Konczne Benedicty, Z.; Szita, E. Acanthococcidae and Related Families of the Palaearctic Region; Plant Protection Institute, Centre for Agricultural Research, Hungarian Academy of Sciences: Budapest, Hungary, 2013; pp. 126-128.

15. Miller, D.R. Selected scale insect groups (Hemiptera: Coccoidea) in the southern region of the United States. Fla. Entomol. 2005, 88, 482-501. [CrossRef]

16. Miller, D.R.; Miller, G.L.; Hodges, G.S.; Davidson, J.A. Introduced scale insects (Hemiptera: Coccoidea) of the United States and their impact on U.S. agriculture. Proc. Entomol. Soc. Wash. 2005, 107, 123-158.

17. Gullan, P.J.; Cook, L.G. Phylogeny and higher classification of the scale insects (Hemiptera: Sternorrhyncha: Coccoidea). Zootaxa 2007, 1668, 413-425.

18. Scalenet: Acanthococcus lagerstroemiae (Kuwana) (Hemiptera: Eriococcidae). Available online: http://scalenet. info/catalogue/eriococcuslagerstroemiae/ (accessed on 22 October 2016).

19. Kondo, T.; Gullan, P.J.; Williams, D. Coccidology, the study of scale insects (Hemiptera: Sternorrhyncha: Coccoidea). Corp. Cienc. Tecnol. Agropecu. 2008, 9, 55-61. [CrossRef]

20. Gullan, P.J.; Kosztarab, M. Adaptations in scale insects. Annu. Rev. Entomol. 1997, 42, 23-50. [CrossRef] [PubMed]

21. Kwon, T.Y.; Park, S.D.; Choi, B.S.; Kwon, Y.J. Seasonal occurrence and chemical control effects of Eriococcus largerstroemiae Kuwana on persimmon trees. Korean J. Appl. Entomol. 1995, 34, 295-299.

22. Gates, Z.; (Texas Forest Service, College Station, TX, USA). Personal communication, 2015.

23. Hoy, J.M. Catalogue of family Eriococcidae. In A Catalogue of the Eriococcidae (Homoptera: Coccoidea) of the World; Owen, R.E., Ed.; New Zealand Department of Scientific and Industrial Research, Government Printer: Wellington, New Zealand, 1963; p. 99.

24. Wang, T. Homoptera: Coccoidea: Pseudococcidae, Eriococcidae, Coccidae, Asterolecaniidae, Lecanodiaspididae, Cerococcidae, Aclerdidae; Science Press: Beijing, China, 2001; pp. 209-210. (In Chinese)

25. Park, J.D.; Kim, Y.H.; Kim, S.S.; Park, I.S.; Kim, K.C. Seasonal occurrence, host preference and hatching behavior of Eriococcus lagerstroemiae. Korean J. Appl. Entomol. 1993, 32, 83-89.

26. Son, J.K.; Park, C.G. Insect pest problems of sweet persimmon in Korea. In Proceedings of the IV International Symposium on Persimmon 833, Firenze, Faenza, Caserta, Italy, 8-13 November 2008; Bellini, E., Giordani, E., Eds.; Acta Hort: Santiago, Chile, 2008; pp. 325-330. 
27. Hua, L. List of Chinese Insects; Zhongshan (Sun Yat-Sen) University Press: Guangdong, China, 2000; p. 137.

28. Kwon, G.M.; Park, K.T. Taxonomic reconsideration of Eriococcidae (Sternorrhyncha) occurring on the persimmon tree, Diospyros kaki Thunb. Korean J. Appl. Entomol. 2002, 41, 305-311. (In Korean)

29. Knox, G. Gardening in the Panhandle: Crape Myrtle Bark Scale in China, and in the U.S.? Available online: http://nwdistrict.ifas.ufl.edu/hort/2014/03/18/crapemyrtle-bark-scale-in-china-and-in-the-u-s / (accessed on 2 June 2016).

30. Varshney, R.K. A Check List of the Scale Insects and Mealy Bugs of South Asia, Part 1; The Pooran Press: Calcutta, India, 1992; p. 152.

31. Williams, D.J. The British and some other European Eriococcidae (Homoptera: Coccoidea). Bull. Br. Mus. Nat. Hist. Entomol. 1985, 51, 347-393.

32. EDDMapS. Early Detection \& Distribution Mapping System. Available online: https://www.eddmaps.org/ distribution/usstate.cfm?sub=21613 (accessed on 29 September 2016).

33. Carol, A.; University District Farmers Market, Seattle, WA, USA. Personal communication, 2016.

34. Phillips, S.J.; Anderson, R.P.; Schapire, R.E. Maximum entropy modeling of species geographic distributions. Ecol. Model. 2006, 190, 231-259. [CrossRef]

35. Russo, N.J.; Cheah, C.A.S.-J.; Tingley, M.W. Experimental evidence for branch-to-bird transfer as a mechanism for avian dispersal of the hemlock woolly adelgid (Hemiptera: Adelgidae). Environ. Entomol. 2016. [CrossRef] [PubMed]

36. Magsig-Castillo, J.; Morse, J.; Walker, G.; Bi, J.; Rugman-Jones, P.; Stouthamer, R. Phoretic dispersal of armored scale crawlers (Hemiptera: Diaspididae). J. Econ. Entomol. 2010, 103, 1172-1179. [CrossRef] [PubMed]

37. Miller, L. NPAG Report Eriococcus lagerstroemiae Kuwana: Crapemyrtle Scale; New Pest Advisory Group: Raleigh, NC, USA, 2015.

38. Merchant, M. Crape Myrtle Bark Scale Reduces Bloom. Available online: http://citybugs.tamu.edu/2014/ 08/14/crape-myrtle-bark-scale-reduces-bloom/ (accessed on 16 May 2016).

39. Robbins, J.; Hopkins, J.; Merchant, M.; Gu, M. Crape Myrtle Bark Scale: A New Insect Pest. Available online: https://www.uaex.edu/publications/PDF/fsa-7086.pdf (accessed on 19 September 2015).

40. Zhang, Y.Z.; Huang, D.W. Two new Encyrtid parasites (Hymenoptera: Chalcidoidea) from China. Orient. Insects 2001, 35, 311-319. [CrossRef]

41. Wang, Y.; Li, C.-D.; Zhang, Y.Z. A taxonomic study of Chinese species of the insidiosus group of Metaphycus (Hymenoptera: Encyrtidae). ZooKeys 2014, 378, 49-81.

42. Zeya, S.B.; Hayat, M. A review of the Indian species of Metaphycus (Hymenoptera: Encyrtidae). Orient. Insects 1993, 27, 185-209. [CrossRef]

43. Hayat, M.; Alam, S.M.; Agarwal, M.M. Indian Insect Types IX: Taxonomic Survey of Encyrtid Parasites (Hymenoptera: Encyrtidae) in India; Aligarh Muslim University: Aligarh, India, 1975; p. 84.

44. Yu, H.; (Beijing Forestry University, Beijing, China). Personal communication, 2016.

45. Hendrickson, R.M.; Drea, J.J.; Rose, M. A distribution and establishment program for Chilocorus kuwanae (Silvestri) (Coleoptera: Coccinellidae) in the United States. Proc. Entomol. Soc. Wash. 1991, 93, 197-200.

46. Vafaie, E. Crapemyrtle Bark Scale Efficacy Trials. Available online: http://sixleggedaggie.com/2014/09/10/ crape-myrtle-bark-scale-efficacy-trial/ (accessed on 10 September 2016).

47. Wang, Z.; Chen, Y.; Diaz, R. The Cactus Lady Beetle: A Voracious Predator of Scale Insects. Available online: http:/ / entomology.lsu.edu/assets/thecactusladybeetle.pdf (accessed on 17 May 2016).

48. DeBach, P.; Rosen, D. Armoured scale insects. In Studies in Biological Control; Delucchi, V.L., Ed.; Cambridge University Press: London, UK; New York, NY, USA, 1976; pp. 139-178.

49. Hattinghl, V.; Samways, M. Physiological and behavioral characteristics of Chilocorus spp. (Coleoptera: Coccinellidae) in the laboratory relative to effectiveness in the field as biocontrol agents. J. Econ. Entomol. 1994, 87, 31-38. [CrossRef]

50. Hill, M.; Allan, D.; Henderson, R.; Charles, J. Introduction of armoured scale predators and establishment of the predatory mite Hemisarcoptes coccophagus (Acari: Hemisarcoptidae) on latania scale, Hemiberlesia lataniae (Homoptera: Diaspididae) in kiwifruit shelter trees in new zealand. Bull. Entomol. Res. 1993, 83, 369-376. [CrossRef]

51. Charles, J.; Hill, M.; Allan, D. Releases and recoveries of Chilocorus spp. (Coleoptera: Coccinellidae) and Hemisarcoptes spp. (Acari: Hemisarcoptidae) in kiwifruit orchards: 1987-1993. N. Z. J. Zool. 1995, 22, 319-324. [CrossRef] 
52. Chen, Y.; Zhang, J. Control experiment on Eriococcus lagerstroemiae Kuwana in Guangdong area. Hubei For. Sci. Technol. 2012, 2, 26-27. (In Chinese)

53. Zhang, Z. Biological characteristics of Eriococcus lagerstroemiae Kuwana and its chemcial cotnrol. Pract. For. Technol. 2010, 2, 32-34. (In Chinese)

54. Kilpatrick, R. Crape Myrtle Bark Scale. Available online: http://www.lsuagcenter.com/portals/our_offices/ parishes/bossier/features/forestry_wildlife/crape-myrtle-bark-scale (accessed on 2 June 2016).

55. Nelms, B.; Louisiana State Unviersity Shreveport Campus, Shreveport, LA, USA. Personal communication, 2015.

56. Chen, Y.; Stagg, J.; Louisiana State University Agriculture Center Hammond Research Station, Hammond, LA, USA. Personal observation, 2015.

57. Desneux, N.; Decourtye, A.; Delpuech, J.M. The sublethal effects of pesticides on beneficial arthropods. Annu. Rev. Entomol. 2007, 52, 81-106. [CrossRef] [PubMed]

58. Diaz, R.; Overholt, W.A.; Cuda, J.; Pratt, P.D.; Fox, A. Temperature-dependent development, survival, and potential distribution of Ischnodemus variegatus (Hemiptera: Blissidae), a herbivore of west Indian marsh grass. Ann. Entomol. Soc. Am. 2008, 101, 604-612. [CrossRef]

59. Zhao, L.; Jia, D.; Yuan, X.; Guo, Y.; Zhou, W.; Ma, R. Cold hardiness of the biological control agent, Agasicles hygrophila, and implications for its potential distribution. Biol. Control 2015, 87, 1-5. [CrossRef]

60. Manrique, V.; Diaz, R.; Montemayor, C.; Serrano, D.; Cave, R.D. Temperature-dependent development and cold tolerance of Microtheca ochroloma (Coleoptera: Chrysomelidae), a pest of cruciferous crops in the southeastern United States. Ann. Entomol. Soc. Am. 2012, 105, 859-864. [CrossRef]

61. Burgi, L.P.; Mills, N.J. Cold tolerance of the overwintering larval instars of light brown apple moth Epiphyas postvittana. J. Insect Physiol. 2010, 56, 1645-1650. [CrossRef] [PubMed]

62. Lapointe, S.L.; Borchert, D.M.; Hall, D.G. Effect of low temperatures on mortality and oviposition in conjunction with climate mapping to predict spread of the root weevil Diaprepes abbreviatus and introduced natural enemies. Environ. Entomol. 2007, 36, 73-82. [CrossRef]

63. Pollock, D. Pomegranate Interest Expands across California Agriculture. Available online: http://westernfarmpress. com/orchard-crops/pomegranate-interest-expands-across-california-agriculture?page=2 (accessed on 2 June 2016).

64. Wapshere, A. A testing sequence for reducing rejection of potential biological control agents for weeds. Ann. Appl. Biol. 1989, 114, 515-526. [CrossRef]

65. Diaz, R.; Manrique, V.; Munyaneza, J.E.; Sengoda, V.G.; Adkins, S.; Hendricks, K.; Roberts, P.D.; Overholt, W.A. Host specificity testing and examination for plant pathogens reveals that the gall-inducing psyllid calophya latiforceps is safe to release for biological control of brazilian peppertree. Entomol. Exp. Appl. 2015, 154, 1-14. [CrossRef]

66. Heard, T. Host range testing of insects. In Biological Control of Weeds: Theory and Practical Application; Julien, M., White, G., Eds.; ACIAR Monograph Series: Canberra, Australia, 1997; pp. 77-82.

67. Forno, W.; Heard, T. Compiling a plant list for testing the host range of agents. In Biological Control of Weeds: Theory and Practical Application; Julien, M., White, G., Eds.; ACIAR Monograph Series: Canberra, Australia, 1997; pp. 71-76.

68. Wessels, F.J.; Cuda, J.P.; Johnson, M.T.; Pedrosa-Macedo, J.H. Host specificity of Tectococcus ovatus (Hemiptera: Eriococcidae), a potential biological control agent of the invasive strawberry guava, Psidium cattleianum (Myrtales: Myrtaceae), in Florida. BioControl 2007, 52, 439-449. [CrossRef]

69. Stout, M.J. Reevaluating the conceptual framework for applied research on host-plant resistance. Insect Sci. 2013, 20, 263-272. [CrossRef] [PubMed]

70. Herbert, J.J.; Mizell, R.F.; McAuslane, H.J. Host preference of the crapemyrtle aphid (Hemiptera: Aphididae) and host suitability of crapemyrtle cultivars. Environ. Entomol. 2009, 38, 1155-1160. [CrossRef] [PubMed]

71. Cabrera, R.I.; Reinert, J.A.; McKenney, C.B. Differential resistance among crape myrtle (Lagerstroemia) species, hybrids, and cultivars to foliar feeding by adult flea beetles (Altica litigata). HortScience 2008, 43, 403-407.

72. Aasen, E. Mckinney Is Crape Myrtle Central, with Thousands of Trees in Summer Bloom. Available online: http:/ / www.dallasnews.com/news/community-news/mckinney/headlines/20120705-mckinneyis-crape-myrtle-central-with-thousands-of-trees-in-summer-bloom.ece (accessed on 16 June 2016).

73. Lacomme, C. Strategies for altering plant traits using virus-induced gene silencing technologies. In Plant Gene Silencing: Methods and Protocols, 1st ed.; Mysore, K., Senthil-Kumar, M., Eds.; Humana Press: New York, NY, USA, 2015; pp. 25-41. 
74. Van Lenteren, J.C. The state of commercial augmentative biological control: Plenty of natural enemies, but a frustrating lack of uptake. BioControl 2012, 57, 1-20. [CrossRef]

75. Hoddle, M.S. Classical biological control of arthropods in the 21st century. In Proceedings of the 1st International Symposium on Biological Control of Arthropods, Honolulu, HI, USA, 14-18 January 2002; USDA Forest Service: Morgantown, WV, USA, 2003; pp. 3-16.

76. Naranjo, S.E.; Ellsworth, P.C.; Frisvold, G.B. Economic value of biological control in integrated pest management of managed plant systems. Annu. Rev. Entomol. 2015, 60, 621-645. [CrossRef] [PubMed]

77. Bokonon-Ganta, A.H.; de Groote, H.; Neuenschwander, P. Socio-economic impact of biological control of mango mealybug in Benin. Agric. Ecosyst. Environ. 2002, 93, 367-378. [CrossRef]

78. Myrick, S.; Norton, G.W.; Selvaraj, K.N.; Natarajan, K.; Muniappan, R. Economic impact of classical biological control of papaya mealybug in India. Crop Prot. 2014, 56, 82-86. [CrossRef]

79. Kairo, M.T.K.; Pollard, G.V.; Peterkin, D.D.; Lopez, V.F. Biological control of the hibiscus mealybug, Maconellicoccus hirsutus green (Hemiptera: Pseudococcidae) in the caribbean. Integr. Pest Manag. Rev. 2000, 5, 241-254. [CrossRef]

80. Agricultural Research Service (USDA). Plant Hardiness Zone Map in the U.S. Available online: http: / / planthardiness.ars.usda.gov/phzmweb/interactivemap.aspx (accessed on 22 October 2016).

81. Van Lenteren, J.C.; Babendreier, D.; Bigler, F.; Burgio, G.; Hokkanen, H.M.T.; Kuske, S.; Loomans, A.J.M.; Menzler-Hokkanen, I.; Van Rijn, P.C.J.; Thomas, M.B.; et al. Environmental risk assessment of exotic natural enemies used in inundative biological control. BioControl 2003, 48, 3-38. [CrossRef]

82. Chong, J.; Oetting, R.D. Specificity of Anagyrus sp. Nov. Nr. Sinope and Leptomastix dactylopii for six mealybug species. BioControl 2006, 52, 289-308. [CrossRef]

83. Caltagirone, L.; Doutt, R. The history of the vedalia beetle importation to California and its impact on the development of biological control. Annu. Rev. Entomol. 1989, 34, 1-16. [CrossRef]

84. Causton, C.E.; Lincango, M.P.; Poulsom, T.G. Feeding range studies of Rodolia cardinalis (Mulsant), a candidate biological control agent of Icerya purchasi Maskell in the Galapagos islands. Biol. Control 2004, 29, 315-325. [CrossRef]

85. Sakthivel, N. Effectiveness of three introduced encyrtid parasitic wasps (Acerophagus papayae, Anagyrus loecki and Pseudleptomastix mexicana) against papaya mealybug, Paracoccus marginatus, infesting mulberry in Tamil Nadu. J. Biopestic. 2013, 6, 71-76.

86. Wang, Z. Department of Entomology, Louisiana State University, Baton Rouge, LA, USA. Personal observation, 2015.

87. Mani, M.; Krishnamoorthy, A. Biological suppression of the mealybugs Planococcus citri (Risso), Ferrisia virgata (Cockerell) and Nipaecoccus viridis (Newstead) on pummelo with Cryptolaemus montrouzieri Mulsant in India. J. Biol. Control 2008, 22, 169-172.

88. Eliopoulos, P.A.; Kontodimas, D.C.; Stathas, G.J. Temperature-dependent development of Chilocorus bipustulatus (Coleoptera: Coccinellidae). Environ. Entomol. 2010, 39, 1352-1358. [CrossRef] [PubMed]

89. Rosado, J.; Bacci, L.; Martins, J.; Silva, G.; Gontijo, L.; Picanço, M. Natural biological control of green scale (Hemiptera: Coccidae): A field life-table study. Biocontrol Sci. Technol. 2014, 24, 190-202. [CrossRef]

90. Henderson, R.C.; Hill, M.G.; Wigley, P.J. Freeze-dried artificial diets for three species of Chilocorus ladybirds. N. Z. Entomol. 1992, 15, 83-87. [CrossRef]

91. Clercq, P.D. Culture of natural enemies on factitious foods and artificial diets. In Encyclopedia of Entomology; Capinera, J.L., Ed.; Springer: Dordrecht, The Netherlands, 2008; pp. 1133-1136.

92. Dong, H.; Ellington, J.J.; Remmenga, M.D. An artificial diet for the lady beetle Harmonia axyridis pallas (Coleoptera: Coccinellidae). Southwest. Entomol. 2001, 26, 205-213.

93. Ehler, L.E. Conservation biological control: Past, present, and future. In Conservation Biological Control; Barbosa, P., Ed.; Academic Press: San Diego, CA, USA, 1998; pp. 1-8.

94. Reddy, P.P. Selective pesticides in IPM. In Sustainable Crop Protection under Protected Cultivation; Reddy, P.P., Ed.; Springer: Singapore, 2016; pp. 121-131.

95. Roubos, C.R.; Rodriguez-Saona, C.; Isaacs, R. Mitigating the effects of insecticides on arthropod biological control at field and landscape scales. Biol. Control 2014, 75, 28-38. [CrossRef]

96. Tang, S.; Tang, G.; Cheke, R.A. Optimum timing for integrated pest management: Modelling rates of pesticide application and natural enemy releases. J. Theor. Biol. 2010, 264, 623-638. [CrossRef] [PubMed] 
97. Cloyd, R.A.; Bethke, J.A. Impact of neonicotinoid insecticides on natural enemies in greenhouse and interiorscape environments. Pest Manag. Sci. 2011, 67, 3-9. [CrossRef] [PubMed]

98. Yu, C.; Lin, R.; Fu, M.; Zhou, Y.; Zong, F.; Jiang, H.; Lv, N.; Piao, X.; Zhang, J.; Liu, Y. Impact of imidacloprid on life-cycle development of Coccinella septempunctata in laboratory microcosms. Ecotoxicol. Environ. Saf. 2014, 110, 168-173. [CrossRef] [PubMed]

99. Krischik, V.A.; Landmark, A.L.; Heimpel, G.E. Soil-applied imidacloprid is translocated to nectar and kills nectar-feeding Anagyrus pseudococci (Girault) (Hymenoptera: Encyrtidae). Environ. Entomol. 2007, 36, 1238-1245. [CrossRef]

100. Smith, S.F.; Krischik, V.A. Effects of systemic imidacloprid on Coleomegilla maculata (Coleoptera: Coccinellidae). Environ. Entomol. 1999, 28, 1189-1195. [CrossRef]

101. Rogers, M.; Krischik, V.A.; Martin, L. Effect of soil application of imidacloprid on survival of adult green lacewing, Chrysoperla carnea (Neuroptera: Chrysopidae), used for biological control in greenhouse. Biol. Control 2007, 42, 172-177. [CrossRef]

102. Tabashnik, B.E.; Croft, B.A. Managing pesticide resistance in crop-arthropod complexes: Interactions between biological and operational factors. Environ. Entomol. 1982, 11, 1137-1144. [CrossRef]

103. Acheampong, S.; Stark, J.D. Can reduced rates of pymetrozine and natural enemies control the cabbage aphid, Brevicoryne brassicae (Homoptera: Aphididae), on broccoli? Int. J. Pest Manag. 2004, 50, 275-279. [CrossRef]

104. Hassan, S.A.; Van de Veire, M. Compatibility of pesticides with biological control agents. In Biocontrol in Protected Agriculture; Heinz, K.M., van Driesche, R.G., Parrella, M.P., Eds.; Ball Publishing: Batavia, IL, USA, 2004; pp. 129-147.

(C) 2016 by the authors; licensee MDPI, Basel, Switzerland. This article is an open access article distributed under the terms and conditions of the Creative Commons Attribution (CC-BY) license (http:/ / creativecommons.org/licenses/by/4.0/). 